\section{ROLE OF ZINC IN LOW BIRTH WEIGHT NEONATES}

Aminul Hoque ${ }^{1}$, Shah Md Keramat Ali $^{2}$

Abstract :

Background : Evidence for an effect of zinc supplementation on growth in every young infants in developing countries is scarce and inconsistent.

In Bangladesh, the highest incidence of Low Birth Weight (LBW) is the main cause of neonatal mortality and morbidity. It is hypothesized that LBW neonates is zinc deficient and that might adversely affect postnatal growth. The present study was carried out to measure the effect of zinc supplementation on LBW neonates during the first month of life and to observe the growth pattern of supplemented (zn) with non supplemented group.

Aim and Objective: It is supported by literates that zinc has an effective positive role in the growth and development in children. But evaluation of the effect of zinc on weight gain in LBW not done so our primary objectives are. (1) The study was done to measure the effectiveness of zinc supplementation on weight gain in low birth weight neonates. (2) To list low birth weight (LBW) babies admitted in neonatal ward of Pediatrics Department of Sher-E-Bangla Medical College Hospital, Barisal during one clander year. (3) To supplement Zinc in a group low birth weight neonate and to compare with another group of low birth weight neonate will receive placebo for a period of 28 days along with necessary treatment for both groups. (4) To compare the study group with control to find out where and when zinc have contributed to weight gain, side effect of supplementation and acceptance of supplementation by the neonates.

Materials and methods : In a randomized, double-blind, placebo-controlled trial study of the effect of zinc on weight gain in low birth weight neonates. The study was carried out in the neonatal ward of pediatrics department of Sher-E-Bangla Medical College, Barisal, Bangladesh. The duration of the study was from May '05 to May '07. The research proposal was approved by Faculty of Post-graduate Medical Science and Research, Dhaka University. Ethical clearance was obtained from Bangladesh Medical Research Council (BMRC). One hundred low birth weight neonates were included in this study and the same number of controls matched for birth weight sex, types to LBW, feeding pattern was studied.

1. Associate Prof Pediatric, Sher-e-Bangla medical College Barisal.

2. Professor, Institute of Nutrition and Food Science, University of Dhaka
After randomization and pair matched neonates were grouped into two groups, 100 neonates were included in group A and 100 neonates in group $\mathrm{B}$.

In the first 28 days of life, the A group received Syrup $\mathrm{D}_{1} 2.5 \mathrm{ml}$ /day in and $\mathrm{B}$ group received syrup $\mathrm{D}_{2} 2.5 \mathrm{ml} /$ day.

The syrup administered to the study neonate in two groups were prepared by Orion Laboratories Ltd. drug manufacturing company. Syrup $\mathrm{D}_{1} 2.5 \mathrm{ml}$ contains zinc $5 \mathrm{mg}$ was given to $\mathrm{A}$ group and Placebo $\left(\mathrm{D}_{2}\right)$ for $\mathrm{B}$ group. The two syrups were indistinguishable in taste and color and code of syrup ' $\mathrm{D}_{1}$ ' and ' $\mathrm{D}_{2}$ ' was kept strictly confidential with the pharmacist.

The parents or care giver were instructed to feed syrup $D_{1}$ $2.5 \mathrm{ml}$ or syrup $\mathrm{D}_{2}$ every morning at 10 am to their neonate up to 28 days.

Measurement of weight of case and control without cloth before feeding at 9a.m after 3 days, 7 days, 14 days, 21 days and 28 days and recorded in a record form. The overall supervision was maintained by researcher. At the end of the study the code of syrup was decoded and found ' $\mathrm{D}_{2}$ ' for Placebo and $\mathrm{D}_{1}$ for zinc. Data were analyzed by using statistical software SPSS.

Result : Among the study subjects $54 \%$ of them were male and $46 \%$ were female, of them $78 \%$ were preterm, and were $22 \%$ IUGR. The mean ( \pm SD) birth weight was $1789.50 \pm 228.89 \mathrm{gm}$ is for cases and controls. Three days after birth, weight decreases to $(1610.50 \pm 255.38 \mathrm{gms})$ in cases and to $(1613.00 \pm 215.04 \mathrm{gms})$ in controls. More weight gain in cases than controls was observed after 7 days of birth. Highly significant weight gain after 21 days (2261.50 \pm 296.14 gms) in cases than controls (2165.50 $\pm 243.47 \mathrm{gms}$ ) and 28 days (2665.00 $\pm 331.52 \mathrm{gms})$ in cases observed than controls (2374.00 \pm 410.07 gms). So mean weight after $21^{\text {st }}$ and $28^{\text {th }}$ days of cases was significantly higher $(\mathrm{P}<0.05)$ than that of control group respectively.

Mean weight gain $(31.37 \pm 6.91 \mathrm{gm} /$ day $)$ of cases was significantly higher $(\mathrm{P}<0.000)$ than the mean weight gain $(21.63$ $\pm 5.67 \mathrm{gm} /$ day) of control group. Mean weight of final follow up of zinc group was $2665.00 \pm 331.52$ and placebo group was $2374.00 \pm 4107$. $(\mathrm{P}<0.000)$ when compared with mean birth weight.

Linear curve of effectiveness of the program on weight for age z-score by follow up days. It was found that increment of effectiveness in Zinc group was higher than that of placebo group. Eighty four percent of cases gained weight more than control group. Problems like physiological Jaundice, infection, convulsion, were less in zinc group compared to control group. 
Conclusions : Neonatal mortality in Bangladesh is high as experienced by causes of death during Neonatal period due to low birth weight. The result of the study provide evidence that zinc supplementation in low birth weight enhanced more weight gain and experienced less problems like infection, convulsion and Jaundice. There was no adverse effect in zinc supplementation groups. Therefore, we conclude that zinc supplementation to LBW neonates is beneficial to combat curse of low birth weight.

\section{Introduction}

Zinc is essential for growth. Zinc supplementation accelerated weight gain by increases circulating insulin like growth factor (IGF-I) ${ }^{1-3}$, appetite ${ }^{4,5,6,7}$, improved ingestion of energy and protein ${ }^{8,9,10}$. IGF-I is the mediator of the growth promoting action of growth hormone. Positive effect of zinc supplementation circulating IGF-1 was reported by Payne $^{10}$, Nakamura ${ }^{11}$. Zinc may promote growth through changes in protein synthesis and cell replication, contributing to accumulation of lean tissue ${ }^{11,12}$. Zinc plays a role in nucleic acid metabolism, in many biochemical functions, hormone structure and in genetic transcription factors ${ }^{13,14}$.

Zinc, which has an important immunology and growth promoting role is among micronutrients. Zinc supplementation significantly reduces the incidence of low birth weight ${ }^{15}$. Low birth weight babies born to our rural mother contributes to high infant deaths. So in order find out an easy and low method for effective treat of LBW the present study designed and conducted.

\section{Materials and Methods}

This study was carried out at the Neonatal ward of Sher-EBangla Medical College Hospital, Barisal, Bangladesh. The duration of study was from May 2005 to February 2007. One hundred pairs of Low birth weight neonates were included in this study.

The selection criteria were:

a. Birth weight less than $2.5 \mathrm{~kg}$ (between $1200 \mathrm{gm}$ to $2300 \mathrm{gm}$ ) with gestation period between 28 and 42 weeks.

b Neonates who where admitted in the first day of life and the mother of whom consented to reside in the hospital for continues 28 days.

c. Neonates of mother who did not have history of zinc supplementation during pregnancy.

The exclusion criteria-a.Neonates admitted with respiratory distress syndrome (RDS), Birth Asphyxia, Hypothermia etc. b. The parents did not consent to participate in the study.
In order to obtain quality data, a standard Questionnaire was developed for this study, which included newborn health information; measurement of weights of neonates, gestational age, and any LBW related problems. The questionnaire was pre-tested and finalized before date collection.

\section{Study Procedure :}

After admission a detailed history and thorough clinical examination was done in all cases and controls. Gestational age was assessed according to new Ballared scoring system. Then parents were informed and consent was taken from them after explaining the purpose of the study. Close monitoring was done for study neonates.

The case selection method: 1 Each of the enrolled neonates consecutively by following inclusion and exclusion criteria and was randomized either of the two groups. 2 The case and control were matched by weight, sex, type of LBW and type of feeding.

One hundred pairs, representing 200 neonates were included in the study. After randomization and pair matched neonates were grouped into two groups, 100 neonates were included group $\mathrm{A}$, and 100 neonates in group $\mathrm{B}$.

\section{Zinc Supplement and placebo}

The syrups administered for the neonates of both groups were prepared by Orion Laboratories Ltd., Dhaka-1208. Syrup for the case neonates was prepared by elemental zinc, sucrose, flavor and preservatives as $100 \mathrm{ml}$ in a sealed bottle with beautiful carton of which $2.5 \mathrm{ml}$ contained $5 \mathrm{mg}$ of zinc. The placebo syrup with same color and taste contained sucrose, flavor and preservatives but no zinc. The syrups were labeled as $\mathrm{D}_{1} \& \mathrm{D}_{2}$ and these codes were kept confidential with the pharmacist. Neither the investigator nor the subjects knew the intervention agent. The two syrups were indistinguishable in presentation. At the end of the study the code of $D_{1} \& D_{2}$ syrup was decoded and found $\mathrm{D}_{1}$ contained zinc and $\mathrm{D}_{2}$ was placebo. In the first 28 days of life, the neonates of group A received labeled D 1 syrup at a dose of $2.5 \mathrm{ml}$ and group B received $2.5 \mathrm{ml}$ of syrup labeled as $\mathrm{D}_{2}$ per day. The mother or care-giver of each child was taught individually how to administer the syrup by using disposable syringe and advised to give child the daily dose up to 28 days. The parents or care giver were instructed to feed syrup $D_{1} 2.5 \mathrm{ml}$ or syrup $\mathrm{D}_{2}$ every morning at 10 am to their neonate up to 28 days.

\section{Results}

Measurement of weight of case and control without cloth before feeding at 9a.m after 3 days, 7 days, 14 days, 21 days 
and 28 days and recorded in the questionnaire. The overall supervision was maintained by researcher. At the end of the study the code of syrup was decoded and found ' $D_{2}$ ' for Placebo and $\mathrm{D}_{1}$ for zinc. Data were analyzed by using statistical software SPSS.

Among the study subjects $54 \%$ of them were male and $46 \%$ were female, of them 78\% were preterm, and were 22\% IUGR. The mean $( \pm \mathrm{SD}$ ) birth weight was $1789.50 \pm 228.89 \mathrm{gm}$ is for cases and controls. Three days after birth, weight decreases to (1610.50 $\pm 255.38 \mathrm{gms})$ in cases and to (1613.00 $\pm 215.04 \mathrm{gms})$ in controls. More weight gain in cases than controls was observed after 7 days of birth.Highly significant weight gain after 21 days (2261.50 \pm 296.14 gms) in cases than controls (2165.50 $\pm 243.47 \mathrm{gms})$ and 28 days (2665.00 $\pm 331.52 \mathrm{gms})$ in cases observed than controls (2374.00 \pm 410.07 gms). So mean weight after $21^{\text {st }}$ and $28^{\text {th }}$ days of cases was significantly higher $(\mathrm{P}<0.05)$ than that of control group respectively.

Mean weight gain $(31.37 \pm 6.91 \mathrm{gm} /$ day $)$ of cases was significantly higher $(\mathrm{P}<0.000)$ than the mean weight gain $(21.63$ $\pm 5.67 \mathrm{gm} /$ day) of control group. Mean weight of final follow up of zinc group was $2665.00 \pm 331.52$ and placebo group was $2374.00 \pm 4107$. $(\mathrm{P}<0.000)$ when compared with mean birth weight.

It was found that increment of effectiveness in Zinc group was higher than that of placebo group. Eighty four percent of cases gained weight more than control group. Problems like physiological Jaundice, infection, convulsion, were less in zinc group compared to control group.

Table- 1 : Multiple comparisons among the outcome of zinc supplemented and without zinc supplemented groups

\begin{tabular}{|c|c|c|c|c|c|}
\hline \multirow[t]{2}{*}{ (I) } & \multirow[t]{2}{*}{$(\mathrm{J})$} & \multicolumn{2}{|c|}{ zinc supplementation (cases) } & \multicolumn{2}{|c|}{ without zinc supplementation (control) } \\
\hline & & Mean Difference (I-J) & Sig. & Mean Difference (I-J) & Sig. \\
\hline \multirow[t]{5}{*}{ Birth weight } & Weight after $3^{\text {rd }}$ day & $179.00 *$ & .000 & $176.50 *$ & .001 \\
\hline & Weight after $7^{\text {th }}$ day & -20.50 & .997 & -14.00 & 1.00 \\
\hline & Weight after $14^{\text {th }}$ day & $-174.50 *$ & .000 & $-168.50 *$ & .002 \\
\hline & Weight after $21^{\text {st }}$ day & $-472.00 *$ & .000 & $-376.00 v$ & .000 \\
\hline & Weight after $28^{\text {th }}$ day & $-875.50 *$ & .000 & $-584.50 *$ & .000 \\
\hline \multirow[t]{5}{*}{ After $3^{\text {rd }}$ day } & Birth weight & $-179.00 *$ & .000 & $-176.50 *$ & .001 \\
\hline & Weight after $7^{\text {th }}$ day & $-199.50 *$ & .000 & $-190.50 *$ & .000 \\
\hline & Weight after $14^{\text {th }}$ day & $-353.50 *$ & .000 & $-345.00 *$ & .000 \\
\hline & Weight after $21^{\text {st }}$ day & $-651.00 *$ & .000 & $-552.50 *$ & .000 \\
\hline & Weight after $28^{\text {th }}$ day & $-1054.50 *$ & .000 & $-761.00 *$ & .000 \\
\hline \multirow[t]{5}{*}{ After $7^{\text {th }}$ day } & Birth weight & 20.50 & .997 & 14.00 & 1.00 \\
\hline & After $3^{\text {rd }}$ day & $199.50 *$ & .000 & $190.50 *$ & .000 \\
\hline & Weight after $14^{\text {th }}$ day & $-154.00 *$ & .004 & $-154.50 *$ & .006 \\
\hline & Weight after $21^{\text {st }}$ day & $-451.50 *$ & .000 & $-362.00 *$ & .000 \\
\hline & Weight after $28^{\text {th }}$ day & $-855.00 *$ & .000 & $-570.50 *$ & .000 \\
\hline \multirow[t]{5}{*}{ After $14^{\text {th }}$ day } & Birth weight & $174.50 *$ & .000 & $168.50 *$ & .002 \\
\hline & Weight after $3^{\text {rd }}$ day & $353.50 *$ & .000 & $345.00 *$ & .000 \\
\hline & Weight after $7^{\text {th }}$ day & $154.00 *$ & .004 & $154.50 *$ & .006 \\
\hline & Weight after $21^{\text {st }}$ day & $-297.50 *$ & .000 & $-207.50 *$ & .000 \\
\hline & Weight after $28^{\text {th }}$ day & $-701.00 *$ & .000 & $-416.00 *$ & .000 \\
\hline \multirow[t]{5}{*}{ After $21^{\text {st }}$ day } & Birth weight & $472.00 *$ & .000 & $376.00 *$ & .000 \\
\hline & Weight after $3^{\text {rd }}$ day & $651.00 *$ & .000 & $552.50 *$ & .000 \\
\hline & Weight after $7^{\text {th }}$ day & $451.50 *$ & .000 & $362.00 *$ & .000 \\
\hline & Weight after $21^{\text {st }}$ day & $297.50 *$ & .000 & $207.50 *$ & .000 \\
\hline & Weight after $28^{\text {th }}$ day & $-403.50 *$ & .000 & $-208.50 *$ & .000 \\
\hline \multirow[t]{5}{*}{ After $28^{\text {th }}$ day } & Birth weight & $875.50 *$ & .000 & $584.50 *$ & .000 \\
\hline & Weight after $3^{\text {rd }}$ day & 1054.50* & .000 & $761.00 *$ & .000 \\
\hline & Weight after $7^{\text {th }}$ day & $855.00 *$ & .000 & $570.50 *$ & .000 \\
\hline & Weight after $14^{\text {th }}$ day & $701.00 *$ & .000 & $416.00 *$ & .000 \\
\hline & Weight after $21^{\text {st }}$ day & $403.50 *$ & .000 & $208.50 *$ & .000 \\
\hline
\end{tabular}

* The mean difference is significant at the .05 level.

Multiple comparisons by Post Hoc test of weight by follow up showed that average birth weight after $3^{\text {rd }}$ day of cases was significantly flat $(\mathrm{P}<0.05)$ when compared with average birth weight. Average weight after $3^{\text {rd }}, 7^{\text {th }}, 14^{\text {th }}, 21^{\text {st }}$ and $28^{\text {th }}$ days were significantly different $(\mathrm{P}<0.05)$ when compared to each other. Similar significant results were found in control group (Table 1$)$. 
Table-II: Nutritional status (\%) of the children by weight for age z-score (WAZ) classification

\begin{tabular}{|c|c|c|c|c|c|c|}
\hline \multirow[t]{2}{*}{ Source of variation } & \multicolumn{3}{|c|}{ Cases $(n=100)$} & \multicolumn{3}{|c|}{ Control $(n=100)$} \\
\hline & $\begin{array}{l}\text { WAZ } \leq-3 \text { SD } \\
\text { (Severely under } \\
\text { weight) }\end{array}$ & $\begin{array}{l}\text { WAZ - } 2.99 \text { to }-2 \\
\text { SD (Moderately } \\
\text { under weight) }\end{array}$ & $\begin{array}{l}\text { WAZ }>-2 \text { SD } \\
\text { (Not under } \\
\text { weight) }\end{array}$ & $\begin{array}{l}\text { WAZ } \leq-3 \text { SD } \\
\text { (Severely under- } \\
\text { weight) }\end{array}$ & $\begin{array}{l}\text { WAZ - } 2.99 \text { to - } 2 \\
\text { SD (Moderately } \\
\text { underweight) }\end{array}$ & $\begin{array}{l}\text { WAZ >-2 SD } \\
\text { (Not under } \\
\text { weight) } \\
\end{array}$ \\
\hline Birth weight & 98.0 & 2.0 & 0.0 & 98.0 & 2.0 & 0.0 \\
\hline Weight after $3^{\text {rd }}$ day & 100.0 & 0.0 & 0.0 & 100.0 & 0 & 0.0 \\
\hline Weight after $7^{\text {th }}$ day & 96.0 & 4.0 & 0.0 & 97.0 & 3.0 & 0.0 \\
\hline Weight after $14^{\text {th }}$ day & 85.0 & 15.0 & 0.0 & 85.0 & 15.0 & 0.0 \\
\hline Weight after $21^{\text {st }}$ day & 38.0 & 62.0 & 0.0 & 54.0 & 46.0 & 0.0 \\
\hline Weight after $28^{\text {th }}$ day & 8.0 & 62.0 & 30.0 & 22.0 & 72.0 & 6.0 \\
\hline
\end{tabular}

Table-II shows Nutritional status of the neonates by weight for age z-score classification of cases during baseline showed that severely underweight, moderately underweight and normal were 98 percent, 2 percent and 0 percent respectively. Similar results were found in control group. After final follow up, severely underweight of cases and control group were reduced from 98 percent to 8 percent and 22 percent respectively. On the other hand normal nutrition status of cases and control group increased to 30 percent and 6 percent. According to severely underweight, improvement were 90 percent of cases and 76 percent of control group

Table-III: Types of low birth weight by follow up weight

\begin{tabular}{|c|c|c|c|c|}
\hline \multirow[t]{2}{*}{ Follow up } & \multirow[t]{2}{*}{ Types of low birth weight } & \multirow[t]{2}{*}{$\mathrm{N}$} & \multirow{2}{*}{$\begin{array}{l}\text { Case } \\
\text { Average weight }\end{array}$} & \multirow{2}{*}{$\begin{array}{l}\text { Control } \\
\text { Average weight }\end{array}$} \\
\hline & & & & \\
\hline \multirow[t]{3}{*}{ Birth weight } & Preterm & 78 & 1728.21 & 1728.21 \\
\hline & IUGR & 22 & 2006.82 & 2006.82 \\
\hline & Total & 100 & 1789.50 & 1789.50 \\
\hline \multirow[t]{3}{*}{ Weight after 72 hours } & Preterm & 78 & 1558.33 & 1561.54 \\
\hline & IUGR & 22 & 1713.64 & 1795.45 \\
\hline & Total & 100 & 1592.50 & 1613.00 \\
\hline \multirow[t]{3}{*}{ Weight after 7 days } & Preterm & 78 & 1748.72 & 1742.95 \\
\hline & IUGR & 22 & 2027.27 & 2018.18 \\
\hline & Total & 100 & 1810.00 & 1803.50 \\
\hline \multirow[t]{3}{*}{ Weight after 14 days } & Preterm & 78 & 1898.72 & 1896.15 \\
\hline & IUGR & 22 & 2195.45 & 2177.27 \\
\hline & Total & 100 & 1964.00 & 1958.00 \\
\hline \multirow[t]{3}{*}{ Weight after 21 days } & Preterm & 78 & 2190.38 & 2109.62 \\
\hline & IUGR & 22 & 2513.64 & 2363.64 \\
\hline & Total & 100 & 2261.50 & 2165.50 \\
\hline \multirow[t]{3}{*}{ Weight after 28 days } & Preterm & 78 & 2587.18 & 2310.26 \\
\hline & IUGR & 22 & 2940.91 & 2600.00 \\
\hline & Total & 100 & 2665.00 & 2374.00 \\
\hline \multirow[t]{3}{*}{ Average weight gain (gms/day) } & Preterm & 78 & 30.863 & 21.532 \\
\hline & IUGR & 22 & 33.205 & 22.018 \\
\hline & Total & 100 & 31.378 & 21.639 \\
\hline
\end{tabular}

Table-III showed that mean weight of IUGR group of cases was higher than the mean weight of preterm group across the follow up days. Similarly trend was found in control group. 
Table-IV: Types of feeding by follow up weight

\begin{tabular}{|c|c|c|c|c|}
\hline Follow up & Types of feeding & $\mathrm{N}$ & $\begin{array}{c}\text { Case } \\
\text { Average weight } \\
\end{array}$ & $\begin{array}{c}\text { Control } \\
\text { Average weight } \\
\end{array}$ \\
\hline \multirow{4}{*}{ Birth weight } & $10 \%$ dextrose + Express breast milk by NG tube + breast feeding & 35 & 1555.71 & 1555.71 \\
\hline & Formula feeding + Express breast milk + Breast feeding & 43 & 1847.67 & 1847.67 \\
\hline & Exclusive Breast feeding by suckling & 22 & 2047.73 & 2047.73 \\
\hline & Total & 100 & 1789.50 & 1789.50 \\
\hline \multirow[t]{4}{*}{ Weight after 72 hours } & $10 \%$ dextrose + Express breast milk by NG tube + breast feeding & 35 & 1392.86 & 1394.29 \\
\hline & Formula feeding + Express breast milk + Breast feeding & 43 & 1670.93 & 1675.58 \\
\hline & Exclusive Breast feeding by suckling & 22 & 1756.82 & 1838.64 \\
\hline & Total & 100 & 1592.50 & 1613.00 \\
\hline \multirow[t]{4}{*}{ Weight after 7 days } & $10 \%$ dextrose + Express breast milk by NG tube + breast feeding & 35 & 1578.57 & 1567.14 \\
\hline & Formula feeding + Express breast milk + Breast feeding & 43 & 1869.77 & 1863.95 \\
\hline & Exclusive Breast feeding by suckling & 22 & 2061.36 & 2061.36 \\
\hline & Total & 100 & 1810.00 & 1803.50 \\
\hline \multirow[t]{4}{*}{ Weight after 14 days } & $10 \%$ dextrose + Express breast milk by NG tube + breast feeding & 35 & 1727.14 & 1725.71 \\
\hline & Formula feeding + Express breast milk + Breast feeding & 43 & 2020.93 & 2017.44 \\
\hline & Exclusive Breast feeding by suckling & 22 & 2229.55 & 2211.36 \\
\hline & Total & 100 & 1964.00 & 1958.00 \\
\hline \multirow[t]{4}{*}{ Weight after 21 days } & $10 \%$ dextrose + Express breast milk by NG tube + breast feeding & 35 & 1992.86 & 1955.71 \\
\hline & Formula feeding + Express breast milk + Breast feeding & 43 & 2325.58 & 2216.28 \\
\hline & Exclusive Breast feeding by suckling & 22 & 2563.64 & 2400.00 \\
\hline & Total & 100 & 2261.50 & 2165.50 \\
\hline \multirow[t]{4}{*}{ Weight after 28 days } & $10 \%$ dextrose + Express breast milk by NG tube + breast feeding & 35 & 2392.86 & 2185.71 \\
\hline & Formula feeding + Express breast milk + Breast feeding & 43 & 2724.42 & 2397.67 \\
\hline & Exclusive Breast feeding by suckling & 22 & 2981.82 & 2627.27 \\
\hline & Total & 100 & 2665.00 & 2374.00 \\
\hline
\end{tabular}

Table 3 showed that mean wt of Exclusive Breast feeding by suckling of cases were higher than the mean weight of $10 \%$ dextrose + Express breast milk by NG tube + breast feeding and Formula feeding + Express breast milk + Breast feeding across the follow up days respectively. Similarly trend was found in control group.

\section{Discussion}

The zinc supplemented group gained $84 \%$ weight than control. zinc supplementation accelerated weight gain. Most zinc supplementation trials performed in the United States and Canada on short but well-nourished children did not report a stimulatory effect on weight gain ${ }^{16,17,18}$. Our findings, however, agree with those trials performed in malnourished populations in developing countries where zinc supplementation increased gains in weight and height $t^{5,18,19}$. The weight response of our subjects to zinc supplementation may be explained by their low initial WAZ score. Our study shows a growth response to zinc supplementation in neonates of both sexes, which agrees with the findings of other zinc supplementation studies of malnourished children in developing countries, where zinc deficiency is likely to be severe. However, in children with mild zinc deficiency, increases in growth have usually been greater in boys than in girls, perhaps because of their greater requirement for zinc ${ }^{14,15,16,18,20 .}$. The effect of zinc may result from increased appetite ${ }^{4,5,6,7}$ and improved utilization of energy and protein. Zinc may promote growth through changes in protein synthesis and cell replication, contributing to accumulation of lean tissue ${ }^{113,119}$. Zinc might modulate the biological activity of other micronutrients, such as vitamin A. Zinc availability controls hepatic release of retinal binding protein (RBP) and consequently may modulate the mobilization of hepatic vitamin A stores ${ }^{193}$. Vitamin A deficiency, a major health problem in Vietnam ${ }^{194}$, is also associated with growth retardation and immunodeficiency.

Our results, agree with those of Rosado et a ${ }^{27}$ and Ruel et $\mathrm{al}^{28}$, go further by showing decreased morbidity in zinc-treated children. Our results, however, suggest that decreased occurrence of infectious diseases is not the sole factor 
responsible for the growth-promoting effect of zinc. The stimulatory effect of zinc on growth velocity was still significant after the incidence of infections was controlled for. Further more, Schlesinger et al ${ }^{196}$ reported a growth-stimulating effect of zinc without significant changes in the incidence of infections.

Because IGF-I is the mediator of the growth-promoting action of growth hormone, low circulating IGF-I observed in proteinenergy malnutrition is believed to be responsible for the growth retardation observed in this condition. Experimental zinc deficiency is also associated with low IGF-I in humans and

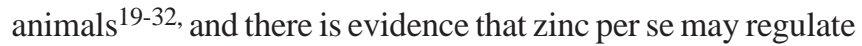
circulating IGF-I concentrations. These observations suggest that zinc deficiency may impair growth by altering circulating IGF-I. Although a positive effect of zinc supplementation on circulating IGF-I was reported previously ${ }^{10}$

In this study mean weight gain $(31.37 \pm 6.91)(\mathrm{p}<0.00)$ in zinc group than the mean weight gain $(21.63 \pm 5.67 \mathrm{gm} /$ day $)$ of control group. It is highly likely that zinc supplements need to be given every day along with appropriate balance diet because there may be no adequate stores of zinc and other nutrients and zinc turnover is also rapid.

The accelerated weight gain in LBW neonates, showed 900 grams in cases and 600gms in controls. Average daily weight gains in cases $32 \mathrm{gms}$ and in controls 21 gms. A study conducted by Sharivastava et al on malnourished children aged 8 to 24 months showed that children supplemented with zinc for 3 months had a significant weight gain $(\mathrm{p}<001)$. Findings of this study agree with those of trials performed in malnourished populations in developing countries where zinc supplementation increased gains in weight. Our suggests that zinc supplementation stimulated growth. The effect of zinc may result from increase appetite and improved ingestion of energy and protein. Zinc may promote growth through changes in protein synthesis and cell replication, contributing to accumulation of lean tissue.

Jaundice is a common problem in low birth weight Neonates. In this study, $15 \%$ of cases and $24 \%$ of controls of low birth weight neonates developed Jaundice. Neonatal infection was more (26\%) in controls but less in cases (7\%). In this study convulsion was $2 \%$ in cases and $3 \%$ in controls, and Apnea was $4 \%$ in cases and $3 \%$ in controls.

\section{References :}

1. Hiltz RL, Suskind R, Amatayakul K. Thanankul O, Olson . Plasmasomatomedin and growth hormone values in children with protein caloric malnutrition. J Pediatr 1978; 92: 153-6.
2. Maiter D, Flieren T, underwood LE, et al. Dietary protein restriction decreases insulin like growth factor 1 independent of insulin and liver growth hormone binding. Endocrinology 1989: 124: 2604-11.

3. Thissen JP. Ketelslegers JM. underwood LE. The nutritional regulation of the insulin like growth factor. Endocr Rev 1994; 15: 80-101.

4. Hambidge KM, Hambidge C, Jacobs M. Baum JD. Low levels of zinc in hair, anorexia, poor growth, and hypogeusia in children. Pediatr Res 1972; 6: 868-74.

5. Cum CX, AnYT, Sheng HJ, Yan MQ, Min HZ, Xiarg LL. Low levels of zinc in hair and blood, pica, anorexia, and poorgrowth in chinese preschool children. Am J clin Nutr 1985; 42: 694-700.

6. Krebs NF, Hambidge KM, Walravens PA. Increase food intake of young children receiving a zinc supplement. Am J Dischild 1984; 138: 270-3.

7. Santizo MC, Rivera J, Ruel MT, et al. The impact of zinc supplementation on nutrient intake from breast milk diet among rural Guatemalan children. FASEB J 1995; 9: A116 (abstr 958).

8. Castillo-Duran C, Heresi G, Fisberg M, Uauy R Controlled trial of zinc supplementation during recovery from malnutrition effect on growth and immune function. Am,J Clin Nutr, 1987; 45: 602-8.

9. Simmer K, Khanum S, Carlsson L, Thomson RPH. Nutritional rehabilitation in Bangladesh the importance of zinc. Amj clin Nutr 1988; 47: 1036-40.

10. Payne-Robinson HM, Golden MHN, Golden BE, Simeon DT, The zinc sandwich and growth. Lancet 1991; 337: 925-6.

11. Nakamura T, Nishiyama S, Fuitagoishi-Suginohara Y, Matsuda I. Higashi A. Mild to moderate zinc deficiency in short children: Effect of zinc supplementation linear growth selocity, J Pediatr 1993; 123: 65-9.

12. Raifen RM Zlotkni S. Microminerals. Tsang RC, lucas A, uauy r, Zlotkni S, editors. Nutrional needs of the preterm.

13. Prasal AS. Discovery of human zinc deficiency and studies in an experimental human model. Amj clin Nutr 1991: 53: 403-12.

14. Prasad AS et al Serum thymulin in human zinc deficiency. Journal of clinical investigation 1988. 82: 1202-1210.

15. Repke JT Villar. J. Pregnancy induced hypertension and low birth weight: Calcium. Amm J Clin Nutr 1991; 54 (1 Suppl) : 2375-2415. 
16. Bhandari B, Sharda B. Zinc in paediatric nutrition and therapy. Indian Pediatr 1980; 17: 293-6.

17. Castillo-Duran C, Garcia H, Venegas P, et al. Zinc supplementation increases growth velocity of male children and adolescents with short stature. Acta Paediatr 1994; 83: 833-7.

18. Bates CJ, Evans PH, Dardenne M, et al. A trial of zinc supplementation in young rural Gambian children. Br J Nutr 1993; 69: 23-55.

19. Bates CJ, Evans PH, Dardenne M, et al. A trial of zinc supplementation in young rural Gambian children Br J Nutr 1993; 69: 243-255.

20. Bhutta ZA, Black RE, Brown KH, et al. Prevention of diarrhea and pneumonia by zinc supplementation in children in developing countries: pooled analysis of randomized controlled trials. Zinc Investigators Collaborative Group.J Pediatr. 1999; 135: 689-697.

21. Jones G, Steketee RW, Black RE, Bhutta ZA, Morris SS, Bellagio Child Survival Study. How many child deaths can we prevent this year? Lancet. 2003; 362: 65-71.

22. Sazawal S, Black RE, Menon VP, et al. Zinc supplementation in infants born small for gestational age reduces mortality: a prospective, randomized, controlled rial. Pediatrics. 2001; 108: $1280-1286$.

23. Krebs NF, Reidinger CJ, Miller LV, Hambidge KM. Zinc homeostasis in breast-fed infants. Pediatr. Res. 1996; 39: 661-665.

24. Umeta M, West CE, Haidar J, Deurenberg P, Hautvast JG. Zinc supplementation and stunted infants in ethiopia: a randomised controlled trial, Lancet. 2001; 355: 2021-2026.
25. Brown KH, Person JM, Allen LH. Effect of zinc supplementation on children's growth: a meta analysis of intervention trials. Bibl Nute Dieta 1998;54:76-83.

26. Blom I, Jameson S, Krook F, Larsson-Symne B, Wranne L. Zinc deficiency with transitory acrodermatitis enteropathica in a boy of low birth weight. Br J Dermatol. 1981; 104: 459-464.

27. Rosado JL, Allen LH, Lopez, P, Martinez H. The effect of zinc and/or iron supplementation on morbidity: a double blind, randomized community trial in Mexican preschoolers. FASEB J 1995; 9: A 157 (abstr 918).

28. Ruel MT. Rivra. J. Brown K. Santizo MC. Lonerdal B. The impact of zinc supplementation in morbidity among young rural Gugtemalan children. ASEB J 1995: 9: A 157 (Abstr 918).

29. Schlesinger L, Arevalo M, Arredondo S, Diaz M, Lonneredal B, Sketel A. Effect of zinc-fortified formula on immunocompetence and growth of malnourished infants. Am J Clin Nutr 1992: 56: 491-8.

30. Oner G, Bhaumic B, Bala RM. Effect of zinc deficiency on serum somatomedin levels and skeletal growth in young rats. Endocrinology 1984; 114:1860-3.

31. Dorup I, Flyvbrjerg A, everts ME, Clauseen T. Role of insulin-like growth factor-I and growth hormone in growth inhibibition induced by magnesium and zinc deficiencies. Br J Nutr 1991; 66:505-21.

32. Ninh NX, Thissen JP, Maiter D, Adam E, Mulumba N, Ketelslegers JM. Reduced liver insulin-like growth factorI gene expression in young zinc-deprived rats is associated with a decrease in liver growth hormone $(\mathrm{GH})$ receptors and serum GH-binding protein. J Endocrinol 1995; 144: 449-56. 